\title{
Integrating Instruction Approach with Learners' Cognitive Style to Enhance EFL Indonesian Students' Writing Achievement
}

\section{Sujito}

Dr., IAIN Surakarta-Jalan Pandawa Pucangan Kartasura Sukoharjo, Indonesia, sujitodoktor@gmail.com

\author{
Wildan Mahir Muttaqin \\ IAIN Surakarta-Jalan Pandawa Pucangan Kartasura Sukoharjo, Indonesia, \\ hellowildan@gmail.com
}

This research was conducted to find the interactive influence between the teaching approach of writing and the type of cognitive style of students to the improvement of students writing ability. There are three teaching approaches applied in this research: product oriented, process oriented and multidimensional approach. Student cognitive style as a moderator variable is divided into three types: Field Independence (FI), Neutral $(\mathrm{N})$ and Field Dependent (FD) cognitive style. The study yielded three findings. First, students who have FI cognitive style experience improved writing skills when they are given product-oriented writing teaching. Students who have $\mathrm{N}$ cognitive style have an increased ability to write higher if they are given multidimensional-oriented writing teaching. Students who have FD cognitive style have high writing skills if they are given process oriented writing teaching. In general, the study recommends the writing teachers use multidimensional-oriented teaching. Researchers also recommend to TEFL practitioners to consider students' cognitive style as one of the learning condition variables. These considerations should be used as a basis for determining teaching methods that are appropriate to the needs of students to produce student optimum achievement.

Keywords: instruction orientation, product-oriented teaching, process-oriented teaching, cognitive style, writing achievement, EFL students

\section{INTRODUCTION}

Psycholinguists often compare writing with swimming in similar characteristic of "species specific-human behavior". Usual skills as walk and talk are universally learned by human beings, but not swimming. In very specific term, some linguists call writing as culturally specific learned behavior (Subha \& Shakil, 2009)(Shams-Abadi, Ahmadi, \&

Citation: Sujito, \& Muttaqin, W. M. (2020). Integrating Instruction Approach with Learners' Cognitive Style to Enhance EFL Indonesian Students' Writing Achievement. International Journal of Instruction, 13(1), 623-636. https://doi.org/10.29333/iji.2020.13140a 
Mehrdad, 2015)(Bruce, 2013) In the area of learning EFL and (ESL) where four common basic skills; auditory skill (listening), oral skill (speaking), text comprehension skill (reading) and text production sill (writing) are required for the students to master, writing is always the most complicated skill hence difficult to teach (Aunurrahman, Abdul Hamied, \& Emilia, 2016) (Sujito et al., 2018). It requires not only grammatical and rhetorical ability but also conceptual and judgmental competence (Sun \& Feng, 2009)(Martinez, Kock, \& Cass, 2011)The teachers of EFL/ESL have long acknowledged that learning to write in English is a complicated process since the complexity of writing is not only made up from the linguistic aspects, also from organization and rhetorical aspects and so do the students. In writing, the students are required to master, to apply the English language rules in sentence level or grammatical elements, then to go beyond sentence level to reach rhetorical elements also conceptual and judgmental competence.

Referring to approach of teaching writing, issues and practices have been familiar with product and process approach. Product and process approaches refer to different notion. A product approach is an instructional program emphasizing on the quality of the students' writing outcomes. It considers whole texts involving the coherence, style, and culture. While process oriented approach is a method of teaching writing focusing on the variety of the learning process (Matsuda, 2003). In cognitive perspective, process oriented approach tries to identify the hidden underlying processes involved in writing. It emphasizes what are known as process to the teaching of writing. (Appleton, Christenson, Kim, \& Reschly, 2006)suggest the teacher may focus on applying the product oriented writing or on the process oriented one. Applying either product or process will result in its different advantages and disadvantages since concentrating on the product only the teacher are only interested in the aim of a task and in the end product. On the other hand, the teacher who applies on a process approach focuses attention to the various stages that any pieces of writing will go through. Meanwhile, (Badger \& White, 2000) states that the disadvantages of process approaches are that the teacher and the students often regard all writing as being produced by the same set of processes. Besides, they give insufficient importance to the kind of texts writers produce and why such texts are produced. Similarly the teacher offer learners insufficient input, particularly in terms of linguistic knowledge to the students to write successfully. However, the process approach has the main advantages. First, the students will understand the importance of the skills involved in writing. The teacher will recognize what they bring to the students in writing classroom contributes to the development of students' writing ability.

The merit and demerit existence labeled to the process and product oriented approach leads some scholars to give suggestion about making combination between the first and second approach. (Brown, 2001) suggest that the teacher should not focus only on the product by leaving process and vice versa, otherwise they will get drowning on the single side disadvantages. It is supported by (Kamimura, 2000) and (Bennui, 2008)with their research finding suggesting that EFL writing teachers in their instruction should maintain a balance between product and process orientations. It is to meet the needs of various EFL writers who come from non-English discourse community. Further, 
(Badger \& White, 2000) proposes the use of process-genre approach to obtain both advantages of process oriented approach and product (genre) oriented approach. The researcher in this study, by some considerations (explained in next chapter of this study), names the combination between product (genre) oriented approach and process oriented approach as multidimensional approach.

In the effort of increasing students' achievement by applying chosen and determined approach or method is really important. However, more important is making sure that the very method or approach is really required by the students. It is not infrequent for the teacher not taking account the unique of the students he teaches. A method supposed to be the most effective method for the learner in a certain condition does not frequently fit with the learner with other condition. Applying a prospective method without scrutinizing its suitability with the learner's unique characteristic will not yield the optimum learning outcome (Martinez et al., 2011). Therefore, besides seeking the best approach in teaching writing, this study is also interested in involving the effort of finding the suitability of the approach to students' characteristic in learning. Student's characteristic is one of the variables in instruction technology. This variable is defined as the personal aspects or qualities of the learner. Those aspects can be cognitive style, learning style, motivation, prerequisite skills, IQ, social norms, religion, and culture. The learner characteristic should be given attention to get the optimum gain in the process of teaching learning. Besides, there are many happening studies about it.

Among other aspects made up the student's characteristic in learning, this study is interested in researching students' cognitive style. In teaching practice, cognitive style is quite crucial because it is the education relevant expressions of the uniqueness of the individual. Besides, writing, the language skill as the focus of this study is decidedly a cognitive process (Díaz Hormazábal, 2007);(Altun \& Izzet, 2006). Therefore, determining to study cognitive style together with studying teaching writing approach is really appropriate.

In context of second and foreign language acquisition, cognitive style receives great attention. It was started by Naiman et al.'s research (Larsen-Freeman, 1991) (Appleton et al., 2006) followed by Tucker, Hamayan and Genesse; Bialystock and Frochlich; Hansen and Stanfield; Chapelle and Robert's in (Larsen-Freeman, 1991) finding the significant link between field independence (one kind of cognitive styles) and communicative competence. In more recent time, some attempts to study cognitive style in the area of EFL/ESL have been also conducted. Some of them are (Bachman, 1990) (Barrot, 2014)studying the ability of the learner with certain kind of cognitive style in doing integrative tests such as the cloze and the oral interview. In another study, (Chapelle \& Roberts, 1986) report significant correlation of field-independence cognitive style (one type of cognitive styles) and cloze test in adult ESL students. To summarize there many scientific reason based on research stating that cognitive style is proved to be one of the important variables determining the success of mastering language skill. Not wanting to be left behind, this study in some extent attempts also to investigate the cognitive style in conjunction with teaching writing orientation in the effort of boosting the EFL students in performing better in writing skill. 
By the above rationale, this study is carried out on the basis of two main reasons; the first, there are still many EFL writing learners who still get difficulty in making argumentative essay especially in terms of linguistic features and rhetoric features, hence finding the best teaching approach in writing among other existing approaches that can foster students' writing achievement is really is really in need. This study for some extent is aimed at this goal. Besides, there has not been a research conducted to examine the suitability between teaching approach in writing and the students' characteristics which, in this study, is specified into cognitive style to boost their achievement. Therefore, based on that need, conducting the study aimed at finding the proof about whether there is any effect of applying process, product and multidimensional oriented teaching in writing instruction to argumentative composition achievement of the third year EFL learners with different cognitive style as well as whether there is interaction between the three is really in great necessity.

The problem statements of this study are:

1. Is there any significant effect of applying writing instruction in three orientations (product oriented writing, multidimensional oriented writing and process oriented writing instruction) on the improvement of the third year EFL students' argumentative writing?

2. Is there any significant effect of the students' cognitive style (field independent cognitive style, neutral cognitive style and field dependent cognitive style) on the improvement of third year EFL undergraduate students' performance in composing argumentative essay?

Is any significant interaction effect of teaching writing in three orientations (product oriented writing, multidimensional oriented writing and process oriented writing instruction) and students' cognitive style (field independent cognitive style, neutral cognitive style and field dependent cognitive style) towards the improvement of the third year EFL undergraduate students' ability in making argumentative composition?

\section{METHOD}

\section{Population and Sample}

The population characteristics targeted by this research are as follows: (1) they are the third year EFL Indonesian students from the study program in non-favorite universities in terms of the quality of input (less qualified freshmen) as explained in background of study; Department of English Education in Faculty of Language and Letters of Kanjuruhan University represents the language and letters based study program from private university; Department of English Education in Faculty of Teacher Training and Education of Islamic University of Malang represents the English language education based study program from private university and English Language Education Study Program in the Department of Letters of State Islamic College (IAIN) Surakarta represents English language education based study program from public university not joining the National Selection of Enrolling Public University, (2) the students are from the university that has sufficient number of students in every academic year, especially 
students at the third year, to be used as the subjects of this study which requires needs a relatively big number of students paralleled in intake classes, (3) the students are from the university that has either relatively flexible rules and policies that enable the researcher to manipulate the available classes or the researcher have broad academic access for certain reason enabling him to do the procedures of the research.

The third year undergraduate EFL students are used as the subject of the study by consideration that they are at the time of taking writing subject (Writing IV) in which the topic about how to write argumentative composition is taught to them. The number of the reached population available in English Language Department of Kanjuruhan University is 249 students, in Islamic University of Malang is 180 students and IAIN Surakarta is 175 students. Factorial design 3x3 with 9 EFL student groups is employed in this research. To meet this requirement, the following procedures are implemented. First, all members of population in every institution are assigned into three groups using GEFT instrument to get three big groups having three different cognitive styles. The three big groups with three different cognitive styles are selected further using stratified random sampling to get 90 students (30 students as sample from every group with different cognitive style). The sample consisting of 90 students that have been classified into three categories on the basis of cognitive style, is randomly assigned further to get 9 (nine) groups. This procedure is done similarly in each department of the three institutions (in English Language Department of Kanjuruhan University, in Islamic University of Malang and in IAIN Surakarta) taken as sample in this study.

\section{Procedure}

This research uses factorial design with randomized subject pre-test post-test group design (Moore, 1983; Wiersma \& Jurs, 2005). The basic representation of the design is described as follows;

\section{$\begin{array}{llll}\mathrm{R} & \mathrm{O}-1 & \mathrm{X} & \mathrm{O}-2\end{array}$}

To this design, extension of more than one treatment as well as more than one control groups is applicable. Since this study has (nine) groups, the above basic design is extended into the following representation (Moore, 1983; Wiersma \& Jurs, 2005)

$\begin{array}{lllll}\text { R } & \text { G-1 -> } & \text { O-1 } & \text { X1 } & \text { O-2 } \\ \text { R } & \text { G-2 -> } & \text { O-1 } & \text { X2 } & \text { O-2 } \\ \text { R } & \text { G-3 -> } & \text { O-1 } & \text { X3 } & \text { O-2 } \\ \text { R } & \text { G-4 -> } & \text { O-1 } & \text { X4 } & \text { O-2 } \\ \text { R } & \text { G-5 -> } & \text { O-1 } & \text { X5 } & \text { O-2 } \\ \text { R } & \text { G-6 -> } & \text { O-1 } & \text { X6 } & \text { O-2 } \\ \text { R } & \text { G-7 -> } & \text { O-1 } & \text { X7 } & \text { O-2 } \\ \text { R } & \text { G-8 -> } & \text { O-1 } & \text { X8 } & \text { O-2 } \\ \text { R } & \text { G-9 -> } & \text { O-1 } & \text { X9 } & \text { O-2 }\end{array}$


The $\mathrm{R}$ refers to random assignment. The $\mathrm{O}$ refers to some process of observation or measurement (pre test and post test) the $\mathrm{X}$ represents exposure to the groups with experimental treatment. The left to the right arrangement reflects the temporal order, and the $\mathrm{X}$ and $\mathrm{O}$ in vertical columns denote simultaneous events.

Firstly, the subjects are assigned into three classifications based on their cognitive style using GEFT/Group Embedded Figure Test (this instrument is explained definitely in instrumentation section) to produce three groups in three cognitive style classifications. The three big groups are randomly selected and assigned into three groups for each to produce nine groups. To the groups, pre-test and treatment as well as post test are given. Pre-test is given in order to know the students' condition before treatment and to fulfil the requirement of randomized subject pre test and post test group design.

\section{Instruments and Assessment}

The data required by this research are; 1) students' cognitive style classification and 2) students' argumentative composition achievement. The data concerning with subjects' cognitive style classification are obtained from the administration of Group Embedded Figure Test (GEFT) instrument. The data obtained are in form of three classifications of the subjects; 1 is for field independent cognitive style subjects, 2 is for neutral cognitive style subjects and 3 is for field dependent cognitive style subjects. The data concerning with subjects' argumentative composition achievement are obtained from the administration of argumentative composition test. The data are in the form of interval data consisting of subjects' composition achievement scores ranging from 1 into 100 .

Basically, to score the students' compositions, a ready made scoring guide called ESL Composition Profile developed by (Jacobs e.t., 1981; Hamp-Lyons, 1981) may be used. However, Jacob's ESL Composition Profile is not considered quite appropriate, because in this research all indicators of composition that are classified into two categories; linguistic features and rhetoric features in order to make the procedure of score easy. In Jacob's, there are five aspects of composition; content, organization, vocabulary, language use and mechanics accordingly. In this research those five aspects are rearranged in such away to match with the two classifications; linguistic features consisting of vocabulary, language use and mechanics and rhetoric features consisting of content and organization.

Concerning with rater reliability, there are intra-rater reliability and inter-rater reliability. Inter-rater reliability were used instead since the last one is usually applied by a classroom teachers who asses their own students for grading purpose. Therefore, to the reliability scores, this study employed two raters. The activity done in the training was explanation and discussion to the test objectives, how to give score the test items and how to use the test scores. After the training was already finished, they were asked to rate the same paper. The scores taken from the two raters were then correlated. The range of the correlation is between $0.00-1.00$. The agreement of the two raters is considered high since the correlation is 0.83 . Since the correlation of the two raters has been proved to be high, the final scores (the raw scores to be analyzed) are determined by taking the average of the scores from rater 1 and rater 2 . To analyze the data, this 
research uses t-test and Two Way ANOVA by employing SPSS 12.0. Although, SPSS 12 is used in this research that may give the researcher simplicity and automaticity, this chapter describes deliberately the mechanical steps of analyzing the data. Before hypothesis testing is conducted, there are some pre-requisites that should be done before. The use of those measurements requires pre-requisites. The pre-requisites are normality and homogeneity of the sample.

\section{FINDINGS}

The data analyzed to test the hypothesis are the post test scores of the students' argumentative composition grouped into nine classifications. The analysis is concerning with interaction effect teaching writing approaches (product oriented writing approach, multidimensional oriented writing approach and process oriented writing approach) and cognitive style of the students (field independent, neutral and field dependent cognitive style) towards argumentative writing performance of the third year EFL undergraduate students.

Table 1

Tests of Between-Subjects Effects

\begin{tabular}{llllll}
\hline Source & Type III Sum of Squares & Df & Mean Square & F & Sig. \\
\hline Corrected Model & $6799.396(a)$ & 8 & 849.925 & 11.346 & .000 \\
Intercept & 1278166.44 & 1 & 1278166.404 & 17062.092 & .000 \\
Teaching & 964.391 & 2 & 482.195 & 6.437 & .002 \\
Cognitive & 543.163 & 2 & 271.581 & 3.625 & .028 \\
Teaching * Cognitive & 5291.843 & 4 & 1322.961 & 17.660 & .000 \\
Error & 19552.200 & 261 & 74.913 & & \\
Total & 1304518.000 & 270 & & & \\
\hline Corrected Total & 26351.596 & 269 & & & \\
\hline
\end{tabular}

a R Squared $=.258$ (Adjusted R Squared $=.235$ )

From the table, it can be seen that the F-ratio for teaching orientation and cognitive style is 17.660 with the degrees of freedom is 4 and $\mathrm{P}$-value is .002. As this research uses significance level .05 $(\alpha=.05)$, if P-value is less than .05, null hypothesis is rejected and if P-value is more .05, null hypothesis is accepted. Since the result of analysis shows that the P-value is .000 , the null hypothesis stating that there is no interactional effect teaching writing approaches (product oriented writing approach, multidimensional oriented writing approach and process oriented writing approach) and cognitive style of the students (field independent, neutral and field dependent cognitive style) towards argumentative writing performance of the third year EFL undergraduate students. is rejected. In technical statement, this research significantly find that there is interactional effect teaching writing approaches (product oriented writing approach, multidimensional oriented writing approach and process oriented writing approach) and cognitive style of the students (field independent, neutral and field dependent cognitive style) towards argumentative writing performance of the third year EFL undergraduate students.

To know the comparison of subjects' writing performance classified by their cognitive style and the teaching orientations given in order to determine the rank, the mean score 
of every group should be reviewed. By looking up the table 2 it can be determined accordingly the position of the subjects' writing performance based on the mean score level of the subjects' argumentative writing achievement gained. The arrangement of the of the rank is as follows; 1) the students' argumentative composition in the group of field independent cognitive style given product oriented teaching in writing (mean score $=75.983), 2$ ) the students' argumentative composition in the group of neutral cognitive style given multidimensional oriented teaching in writing (mean score $=75.783$ ), 3 ) the students' argumentative composition in the group of field dependent cognitive style given process oriented teaching in writing (mean score $=71.367), 4$ ) the students' argumentative composition in the group of field independent cognitive style given multidimensional oriented teaching in writing (mean score $=70.467$ ), 5) the students' argumentative composition in the group of neutral cognitive style given process oriented teaching in writing (mean score $=69.900)$, 6) the students' argumentative composition in the group of field dependent cognitive style given multidimensional oriented teaching in writing (mean score $=67.600$ ), 7) the students' argumentative composition in the group of field independent cognitive style given process oriented teaching in writing (mean score $=64.017$ ), 8) the students' argumentative composition the group of neutral cognitive style given product oriented teaching in writing (mean score $=62.550$ ), 9) the students' argumentative composition mean score in the group of field dependent cognitive style given product oriented teaching in writing (mean score $=61.567$ ).

Table 2

Estimated Marginal Means of Subjects' Argumentative Composition Achievement across Cognitive Styles and Teaching Writing Orientations

\begin{tabular}{|c|c|c|c|c|c|}
\hline \multirow{2}{*}{$\begin{array}{l}\text { Teaching Writing } \\
\text { Orientation }\end{array}$} & \multirow{2}{*}{ Cognitive Style } & \multirow{2}{*}{ Mean } & \multirow{2}{*}{ Std. Error } & \multicolumn{2}{|c|}{ 95\% Confidence Interval } \\
\hline & & & & $\begin{array}{l}\text { Lower } \\
\text { Bound }\end{array}$ & $\begin{array}{l}\text { Upper } \\
\text { Bound }\end{array}$ \\
\hline \multirow[t]{3}{*}{$\begin{array}{l}\text { 1=Product Oriented } \\
\text { Writing }\end{array}$} & 1=Field Independent Style & 75.983 & 1.580 & 72.872 & 79.095 \\
\hline & $2=$ Neutral Style & 62.550 & 1.580 & 59.438 & 65.662 \\
\hline & 3=Field Dependent Style & 61.567 & 1.580 & 58.455 & 64.678 \\
\hline \multirow[t]{3}{*}{$\begin{array}{l}2=\text { Multi Dimensional } \\
\text { Oriented Writing }\end{array}$} & 1=Field Independent Style & 70.467 & 1.580 & 67.355 & 73.578 \\
\hline & $2=$ Neutral Style & 75.783 & 1.580 & 72.672 & 78.895 \\
\hline & 3=Field Dependent Style & 67.600 & 1.580 & 64.488 & 70.712 \\
\hline \multirow[t]{3}{*}{$\begin{array}{l}3=\text { Process Oriented } \\
\text { Writing }\end{array}$} & 1=Field Independent Style & 64.017 & 1.580 & 60.905 & 67.128 \\
\hline & $2=$ Neutral Style & 69.900 & 1.580 & 66.788 & 73.012 \\
\hline & 3=Field Dependent Style & 71.367 & 1.580 & 68.255 & 74.478 \\
\hline
\end{tabular}

By observing the mean scores gained by every subject group, it can be inferred that there is an interesting combination between the style of cognitive the subjects have and the teaching orientation given to them. The students in field independent style category achieve higher writing performance when they are given product oriented writing approach based treatment, but those in the same cognitive style get less writing performance when they are given the other two writing approaches. Another fact shows multidimensional oriented teaching applied to the student having neutral cognitive style results in good writing achievement rather than if it is applied to the subjects in the group independent and dependent cognitive style. Similarly, the students in dependent 
cognitive style category experience argumentative writing performance increased significantly after they are given process oriented teaching. However, the writing achievement gets decreased when other subjects in the same cognitive style category are given the other writing approaches. This fact leads to the existence of interaction between students' argumentative composition achievement, teaching writing orientation and students' cognitive style. The clear visual interaction is displayed in figure 4.30.

The horizontal axis represents teaching writing orientation, whereas the vertical axis represents the students' argumentative writing scores. The three styles of students' cognitive are represented by the three lines differentiated using different printing solidity.

Estimated Marginal Means of Score Of Writing Test

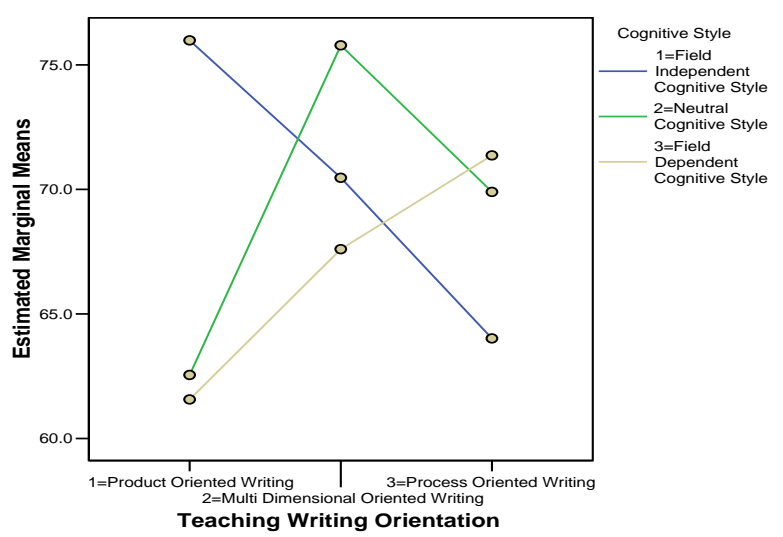

Figure 1

Profile of Interaction between the Students Argumentative Achievement across Cognitive Styles and Teaching Writing Orientations

The solid printed line represents the group of independent cognitive style. The rare dashed line represents the subjects having neutral cognitive style and the last, the frequent dashed one, is for dependent cognitive style.

\section{DISCUSSION}

As has been explain in the section of examining the interactional effect of teaching writing approach and students' cognitive styles towards their argumentative writing performance, this research discloses the new propositions in foreign language teaching practice. The certain teaching strategy is only effective if it is combined with the students' characteristics. Teaching strategy is useless or even sacrifices the students' opportunity to be success in language learning if it is wrongly applied. Students as human in general have their own characteristics that need attention and treatment as they require personally hence fostering optimally their potency (Appleton et al., 2006; Barrot, 2014; Galbraith, 2009) . Referring to the teaching approach matched with the 
students' characteristic, the finding of this research explicitly reveals that product oriented teaching in writing is effective in increasing the argumentative composition achievement if it is given to EFL students' with independent cognitive style. This statement can be reversed by emphasizing the students' characteristics to be the students with field independent cognitive style will achieve high achievement in making argumentative composition only if they are given product oriented teaching in writing. The EFL students with field independent cognitive style are not recommended to be given teaching writing orientation other than product oriented. Otherwise it will make their achievement decreased. Process oriented teaching and multidimensional oriented teaching in writing is not suitable with the need of EFL students with field independent cognitive style.

Product oriented writing approach is suitable for the learners in field independent cognitive style category. Field Independent learners have a tendency to restructure the environment/context given with the dominant organization different from the field dependent learners who have a tendency to follow the environment or the context given(Guisande, Páramo, Tinajero, \& Almeida, 2007; Meskill \& Rangelova, 2000) . FI learner lacks of social orientation and social modality compared with FD learner. Therefore, process oriented teaching is not match with their need. This approach is not advantageous to them because FI learner prefers physical subjects. They do not prefer social and oral linguistics as the process approach gives(Galbraith, 2009). FI learner is likely to be individualistic, not cooperative. Instead of preferring the teaching approach having the steps like process approach that make them lose of focus, the product oriented approach strengthens their analytical capability. Their ability to see the component inside that can be used to help solving the problem quickly can be build by product oriented approach. The product oriented approach is also able to develop their tendency to restructure the environment/context given with the dominant organization. The students with Field Independent Cognitive Style (FI) have strong analytic skills and ability to easily separate key details from a complex or confusing background. Those skills are required very much in making argumentative composition. Therefore, giving them teaching approach that enables them to work individually makes their achievement in writing argumentative composition fostered (Greene, Miller, Crowson, Duke, \& Akey, 2004) Greene, B.A shows how learners having analytic or field independent cognitive style learn. He suggests ways in which they should be taught. According to them the characteristics of analytic learner are step by step learner. They tend to build cumulative sequential pattern towards a concept. They prefer quiet and formal design with complete literature. Strong willingness to complete the task they are working on is also some of their characteristics. Their response to words and numbers is very well. Visual re-enforcement, direction, fact sheets, underlining important sections, feedback on details and in sequence are necessary task for them. The independent or analytic learners' characteristics above support and add the conviction of what has been found by this research that product oriented approach is the approach really required by the independent or analytic EFL learners. Process oriented approach will bother their opportunity to learn and to explore their potency because the independent or analytic EFL learners have orientation without reference or connection. The social material they 
learn is only as an on their purpose task. The independent or analytic EFL learners do not need the steps in process oriented approach since they are interested in new concepts. Besides they have self-defined goals. They are also able to reinforce and structure any situations by themselves. Their preference to learn in quiet, well lit and formal design is really match with the procedure in product oriented approach. It is the procedure of learning they indeed need that can help fostering their achievement, without wasting the time following the steps and social reciprocal activity suggested by the process oriented one.

The suggestions must not be deliberately aimed at referring to one of the three approaches (product, process and multidimensional oriented teaching) investigated by this research. Those are free from that intention. However, what has been suggested by them to teach for the EFL learner having independent cognitive style is really in line with the procedures of product oriented teaching in writing. EFL learner having independent cognitive style should be taught by teaching situations with specific reference to a particular person such as lectures that emphasizes cognitive aspects of instruction. They need a teacher-organized learning situation that gives them corrective feedback. Product oriented approach by using write-rewrite for example is also aimed at giving feedback to the learner.

The existence of the interaction between students' argumentative composition achievement, teaching writing orientation and students' cognitive style as displayed in figure 1 also shows that the students in field dependent cognitive style category experience high gain in argumentative writing performance after they are treated using process oriented teaching. However, their writing achievement gets decreased when the subjects are given the other teaching orientations. The students in field dependent cognitive style category will achieve higher achievement in composing argumentative writing only if they are treated using process oriented teaching approach. The EFL field dependent cognitive style students are not recommended to be given teaching writing orientation other than process oriented approach. Their achievement will not be optimum if not get decreased instead. Product oriented teaching and multidimensional oriented teaching in writing is not suitable with the need of EFL students with field dependent cognitive style. Field dependent cognitive style learners are socially oriented whereas field independent cognitive learners are not (Witkin, 1971). Field dependent learner is likely to cooperative and easy to learn in group. Social cues are their attention and interest. They enjoy with others and they seek learning and experiences by having contact with other people. Moreover unlike field independent learner, field dependent learners perform less well on formal operations tasks (Galbraith, 2009). By those characteristics, they need the procedure of teaching as suggested by process oriented approach. As suggested by (Greene et al., 2004) the learner having such kind of cognitive style will prefer teaching situations that enable interaction and discussion among the students. They also prefer the use of questions to check on their learning progress in following instruction. Teaching that apply student-centered activities interests them as this kind of teaching avoids negative evaluation. The students in this kind have also interest in strong and warm establishment enabling personal learning environment 
Next is concerning with neutral cognitive style students and multidimensional oriented approach. Research finding concerning with the comparison among the three orientations in teaching writing described in the first part of the second section of this research report shows that the students given multidimensional oriented teaching gained the highest argumentative composition achievement compared with the group given other teaching writing orientation. Even, when the students given process oriented teaching, they have less achievement compared with the groups given the multidimensional one. In Table 2 concerning with the Estimated Marginal Means of Subjects' Argumentative Composition Achievement across Cognitive Styles and Teaching Writing Orientations and Figure 1 about Profile of Interaction between the Students Argumentative Achievement across Cognitive Styles and Teaching Writing Orientations shows that multidimensional oriented teaching in writing is only effective if it is given to the students having neutral cognitive style. It is really true that the certain teaching strategy is only effective if it is combined with the students' characteristics.

Although multidimensional oriented is expected to be the solution bridging the gap between the things that cannot be covered by both process and product oriented teaching, it suggested not to apply this approach too confidently by giving it to all students with all characteristics. Multidimensional oriented teaching in writing is only effective if it is given to the students having neutral cognitive style. Multidimensional oriented teaching in writing does not extremely foster the argumentative composition achievement of the students in field independent and in field dependent cognitive style category. Increasing the writing achievement of the neutral cognitive style students can be done by giving them the teaching approach using the mix or the combination of process and product since the characteristics of them is in between field independence and field dependence. Multidimensional oriented teaching in writing as the balance combination between product and process is very effective to be applied for the students having neutral cognitive style. As proposed (Guisande et al., 2007)(Galbraith, 2009) neutral cognitive style person characteristics is the combination characteristics of both field independent and field dependent cognitive style, that is, neutral cognitive style.

\section{REFERENCES}

Altun, A., \& Izzet, A. (2006). Undergraduate Students' academic achievement, field dependent/independent cognitive styles and attitude toward computers. Educational Technology \& Society. 9(1), 289-297.

Appleton, J. J., Christenson, S. L., Kim, D., \& Reschly, A. L. (2006). Measuring cognitive and psychological engagement: Validation of the student engagement instrument. Journal of School Psychology, 44(5), 427-445. https://doi.org/10.1016/j.jsp.2006.04.002.

Aunurrahman, A., Abdul Hamied, F., \& Emilia, E. (2016). Facilitating character building through an academic writing practice. SSRN, 7(3), 146-160. https://doi.org/10.2139/ssrn.2859247.

Bachman, L. F. (1990). Fundamental considerations in language testingOxford: Oxford University Press. 
Badger, R., \& White, G. (2000). A process genre approach to teaching writing. ELT Journal, 54(2), 153-160. https://doi.org/10.1093/elt/54.2.153.

Barrot, J. S. (2014). A macro perspective on key issues in English as second language (ESL) Pedagogy in the postmethod era: Confronting challenges through sociocognitivetransformative approach. Asia-Pacific Education Researcher, 23(3), 435-449. https://doi.org/10.1007/s40299-013-0119-4.

Bennui, P. (2008). A study of L1 interference in the writing of Thai EFL students. Malaysian Journal of ELT Research, 4(1).

Brown, H. D. (2001). Teaching by principles: An interactive approach to language pedagogy. Tesol Quarterly, 35(2), 341-342. https://doi.org/10.2307/3587655.

Bruce, I. (2013). A role for genre-based pedagogy in academic writing instruction? An EAP perspective. TEXT Special Issue 21: Scores from another ground, 21, 1-15.

Chapelle, C., \& Roberts, C. (1986). Ambiguity tolerance and field independence as predictors of proficiency in English as a second language. Language Learning, 36, $27-$ 45. https://doi.org/10.1111/j.1467-1770.1986.tb00367.x.

Díaz Hormazábal, R. (2007). Argumentative writing strategies and perceptions of writing in academia by EFL college students. Literatura y Lingüística, 18, 263-282. https://doi.org/10.4067/S0716-58112007000100015.

Galbraith, D. (2009). Cognitive models of writing. German as a Foreign Language, 2$3,7-22$.

Greene, B. A., Miller, R. B., Crowson, H. M., Duke, B. L., \& Akey, K. L. (2004). Predicting high school students' cognitive engagement and achievement: Contributions of classroom perceptions and motivation. Contemporary Educational Psychology, 29(4), 462-482. https://doi.org/10.1016/j.cedpsych.2004.01.006.

Guisande, M. A., Páramo, M. F., Tinajero, C., \& Almeida, L. S. (2007). Field dependence-independence (FDI) cognitive style: An analysis of attentional functioning. Psicothema, 19(4), 572-527.

Hamp-Lyons, L. (1984). T Book reviews : Jacobs, H.L., Zingraf, S.A. Wormuth, D.R., Hartfiel, V.F. and Hughey, J.B. 1981: Testing ESL composition: a practical approach. Rowley, Massachusetts: Newbury House. xii + 139 pp. ISBN 0-88377-225-6 (v.1). Language Testing, 1(2), 241-244. https://doi.org/10.1177/026553228400100210.

Jacobs, H. L., \& others. (1981). Testing ESL composition: A Practical approach. english composition program. Rowley, MA: Newbury House.

Kamimura, T. (2000). Integration of process and product orientations in EFL writing instruction. RELC Journal, 31(2), 1-28. https://doi.org/10.1177/003368820003100201.

Larsen-Freeman, D. (1991). Second language acquisition research: Staking out the territory. Tesol Quarterly, 25(2), 315-350. https://doi.org/10.2307/3587466. 
Martinez, C. T., Kock, N., \& Cass, J. (2011). Pain and pleasure in short essay writing: Factors predicting university students' writing anxiety and writing self-efficacy. Journal of Adolescent \& Adult Literacy, 54, 351-360. https://doi.org/10.1598/JAAL.54.5.5.

Matsuda, P. K. (2003). Process and post-process: A discursive history. Journal of Second Language Writing, 12(1), 65-83. https://doi.org/10.1016/S1060-3743(02)001273.

Meskill, C., \& Rangelova, K. (2000). Relocating the 'cognitive'in sociocognitive views of second language learning. In R. Rapp (Ed.), Linguistics on the way into the new millennium: Proceedings of the $34^{\text {th }}$ colloquium of linguistics (pp.74-77). London: Peter Lang-Verlag Publishing.

Moore, G. W. (1983). Developing and evaluating educational research. Harpers Collins.

Shams-Abadi, B. B., Ahmadi, S. D., \& Mehrdad, A. G. (2015). The effect of edmodo on EFL learners' writing performance. International Journal of Educational Investigations, 7(1), 153-162. https://doi.org/10.5539/ijel.v7n1p153

Subha, I., \& Shakil, A. (2009). Impact of stress on employee productivity, performance and turnover; An important managerial issue. International Review of Business Research Papers, 5(4), 468-477.

Sujito, Kurniasih, N., Muttaqin, W. M., Sari, I. N., Saleky, A. P., Tuasikal, P., ... Aziz, F. (2018). Applying ELMS technology based teaching strategy to improve writing competence for EFL remedial students across different motivation level. International Journal of Engineering and Technology(UAE), 7(3.2), 770-773.

Sun, C., \& Feng, G. (2009). Process approach to teaching writing applied in different teaching models. English Language Teaching, 2(1), 150-155. https://doi.org/10.5539/elt.v2n1p150

Wiersma, W., \& Jurs, S. G. (2005). Research methods in education: An introduction. Boston, MA: Ally and Bacon.

Witkin, H. A. (1971). Group embedded figures test. PsycTESTS. https://doi.org/10.1037/t06471-000 